HJIMB Vol 1, No. 2 2019, pp: 34-44

https://doi.org/10.30606/hiimb

\title{
HIRARKI
}

Jurnal Ilmiah Manajemen dan Bisnis

http://iournal.upp.ac.id/index.php/Hirarki

\section{PERSPEKTIF KEPEMIMPINAN, DISIPLIN KERJA DAN KOMPENSASI TERHADAP KINERJA SEKOLAH PELITA CAHAYA}

David Humala Sitorus, Heryenzus

Manajenem, Universitas Putera Batam, Batam,

\section{Info Artikel}

Sejarah Artikel:

Diterima 23 Agustus

2019

Disetujui 16 September 2019

Dipublikasikan

30 Oktober 2019

\section{Keywords:}

Kepemimpinan; Disiplin

Kerja; Kompensasi;

Kinerja.

\begin{abstract}
Abstrak
$\overline{\text { Penelitian ini bertujuan untuk mengetahui seberapa besar pengaruh kepemimpinan, }}$ disiplin kerja, kompensasi terhadap kinerja guru di Sekolah Pelita Cahaya baik secara parsial maupun simultan. Penelitian ini menggunakan desain penelitian deskriptif dengan pendekatan kuantitatif. Sampel ditentukan dengan menggunakan sampling jenuh dari 129 responden. Berdasarkan hasil uji statistik diketahui variabel kepemimpinan, disiplin kerja, kompensasi dan kinerja guru adalah data berdistribusi normal, variabel bebas tidak terjadi multikolinieritas dan heteroskedastisitas. Hasil penelitian menunjukkan bahwa kepemimpinan, disiplin kerja, dan kompensasi secara bersamaan memiliki pengaruh yang signifikan terhadap kinerja guru di Sekolah Pelita Cahaya. Variabel kepemimpinan (X1) dan disiplin kerja (X2) berpengaruh positif dan signifikan terhadap variabel kinerja guru (Y), sedangkan variabel kompensasi (X3) berpengaruh negatif dan signifikan terhadap variabel kinerja guru $(Y)$
\end{abstract}

LEADERSHIP PERSPECTIVE, WORK DISCIPLINE AND COMPENSATION TO THE PERFORMANCE OF SCHOOL PELITA CAHA

Abstract
This study aims to determine how much influence the leadership, discipline,
compensation to the performance of teachers at Sekolah Pelita light either
partially or simultaneously. This research uses descriptive research design with a
quantitative approach. Samples were determined using saturation sampling of
129 respondents. Based on the statistical test known variables of leadership,
discipline, compensation and performance of teachers is the normal distribution
of data, independent variables does not happen multicollinearity and
heteroscedasticity. The results showed that the leadership, work discipline, and
compensation simultaneously have a significant influence on the performance of
teachers at Sekolah Pelita Light. Leadership variable (X1) and discipline (X2)
positive and significant impact on teacher performance variable (Y), while the
variable compensation (X3) a significant negative effect on teachers
performance variable (Y)




\section{PENDAHULUAN}

Perkembangan suatu perusahaan pada umumnya dipengaruhi oleh kepemimpinan yang diterapkan di suatu perusahaan tersebut. Karena sumber daya manusia merupakan modal utama dalam merencanakan serta menggerakkan faktor-faktor yang terdapat didalam perusahaan. Pemimpin dituntut untuk dapat meningkatkan kualitas serta keterampilan untuk mengelolah sebuah perusahaan yang dipimpin untuk mengantarkan perusahaan ke tujuan yang direncanakan atau ditetapkan sebelumnya.

Pada zaman era globalisasi saat ini, peningkatan kualitas dan keterampilan sangat diperhatikan baik dalam perkantoran maupun dalam kepemimpinan di bidang pendidikan. Peningkatan kualitas pendidikan yang baik dan bermutu menjadi dasar perkembangan dan kemajuan sebuah sekolah. Oleh sebab itu, pengelola pendidikan harus merespon berbagai kebijakan pemerintah dan keinginan masyarakat dalam kerangka perbaikan mutu dan keratifitas serta strategi manajemen yang baik dalam konteks sistem. Dengan demikian, akan tercipta pendidikan yang lebih baik dan lebih maju untuk bersaing dengan tingkat nasional maupun di tingkat internasional. Pendidikan saat sekarang sudah tidak dapat dibandingkan dengan pendidikan di masa lalu. Maka lembaga pendidikan mempunyai tanggung jawab sosial yang sangat besar kepada bangsa dan Negara ini bukan lagi sebagai sebuah kepentingan bagi semata bisnis, banyak sekali faktor yang mempengaruhi dunia.

pendidikan di antarannya adalah kepemimpinan seorang kepala sekolah.
Dunia pendidikan saat ini telah berkembang sangat pesat dari waktu ke waktu. Pendidikan saat sekarang sudah tidak dapat dibandingkan dengan pendidikan di masa lalu. Maka lembaga pendidikan mempunyai tanggung jawab sosial yang sangat besar kepada bangsa dan negara ini bukan lagi sebagai sebuah kepentingan bagi semata bisnis. Banyak sekali faktor yang mempengaruhi dunia pendidikan di antarannya adalah kepemimpinan seorang kepala sekolah.

Disiplinan yang sering kita ketahui berbagai beberapa unsur yaitu pemanfaatan waktu, mengatur administrasi pendidikan dan melaksanakan tugas dan tanggung jawab, karena disiplin seorang guru akan dapat mempengaruhi besarnya terhadap prestasi belajar siswa, dimana prestasi yang tinggi akan dapat diraih siswa. Apabila didukung displin guru secara baik dalam melaksanakan tugasnya. Seorang guru yang displin dapat ditemukan masalah-masalah yang dapat ditumbulkan pada saat membuat suatu program pembelajaran atau penyampaian suatu materi yang akan disampaikan kepada siswa siswi dalam kelas.

Kepala sekolah sebagai pimpinan tertinggi yang bisa mempengaruhi dan menentukan kemajuan sekolah. Kepala sekolah harus memiliki kemampuan untuk mengadministrasi dan memiliki komitmen yang tinggi untuk melakukan setiap rencana serta tugas yang telah direncanakan. Kepemimpinan kepala sekolah yang baik harus dapat meningkatkan disiplin kerja serta kinerja setiap guru melalui program pembinaan kemampuan tenaga pendidikan. Oleh karena itu pimpinan seorang kepala sekolah harus memiliki kepribadian sifat-sifat dan kemampuan serta 
keterampilan keterampilan untuk membimbing sebuah lembaga kepemimpinan.

Kepala sekolah sebagai pimpinan tertinggi yang bisa mempengaruhi dan menentukan kemajuan sekolah. Kepala sekolah harus memiliki kemampuan untuk mengadministrasi dan memiliki komitmen yang tinggi untuk melakukan setiap rencana serta tugas yang telah direncanakan. Kepemimpinan kepala sekolah yang baik harus dapat meningkatkan disiplin kerja serta kinerja setiap guru melalui program pembinaan kemampuan tenaga pendidikan. Oleh karena itu pimpinan seorang kepala sekolah harus memiliki kepribadian sifat-sifat dan kemampuan serta keterampilan keterampilan untuk membimbing sebuah lembaga kepemimpinan. Seorang guru dituntut untuk dapat memberikan kontribusi yang besar terhadap pendidikan di lingkungan sekolah terutama dalam hal belajar-mengajar, karena keberhasilan siswa sangat ditentukan oleh kinerja guru yang profesional dalam menjalankan tugas, fungsi dan peranannya sebagai seorang pendidik. Seorang guru dituntut menjadi seorang pendidik yang berkualitas dengan kinerja yang bagus dan bertanggung jawab.
Di Sekolah Pelita Kasih kepemimpinan kepala sekolah masih belum kontribusi secara maksimal. Peraturan yang dibuat belum dapat dipertahankan dan di jalankan secara baik dan benar. Karena infomasi yang disampaikan tidak secara maksimal disampaikan kepada setiap rekan guru. Dan kurangnya hubungan interaksi antara kepala sekolah dan guru dan kurangnya motivasi yang diberikan kepala sekolah kepada guru dalam hal masalah yang dihadapi guru terhadap siswa siswi dalam penerimaan materi, kelakuan siswa atau tingkah laku siswa dalam kelas yang dihadapi oleh guru saat proses ngajar mengajar terhadap siswa.

Untuk mencapai kinerja yang tinggi bukan hal mudah untuk dilaksanakan. Disiplin adalah kesadaran dan kesediaan seseorang menaati semua peraturan perusaan dan normal-normal sosial yang berlaku. Dalam melakukan observasi langsung ke lapangan penelitian mendapatkan data berupa laporan absensi karyawan guru Sekolah Pelita Kasih selama tiga bulan berakhir yaitu Juni, Juli, Agustus 2018. Tabel di bawah ini merupakan hasil rekapan dari laporan absensi karyawan guru. Untuk lebih jelasnya dapat dilihat pada tabel 1.2 sebagai berikut:

Tabel 1 Perbandingan Tingkat Ketelambatan Guru dari Bulan Juni - Agustus 2018

\begin{tabular}{|c|c|c|c|c|}
\hline \multirow{2}{*}{ NO } & \multirow{2}{*}{ DAPARTEMEN } & \multicolumn{3}{|c|}{ BULAN } \\
\cline { 3 - 5 } & & JUNI & JULI & AGUSTUS \\
\hline 1 & TK & 1 & 6 & 3 \\
\hline 2 & SD & 18 & 22 & 17 \\
\hline 3 & SMP & 12 & 14 & 13 \\
\hline 4 & SMA & 7 & 7 & 5 \\
\hline 5 & SMK & 4 & 8 & 4 \\
\hline \multicolumn{2}{|c|}{ TOTAL } & 42 & 57 & 42 \\
\hline
\end{tabular}

Sumber: Laporan Absensi Sekololah Pelita Kasih 
Berdasarkan tabel 2 pada bulan Juli terdapat tingkat keterlambatan yang tertinggi yaitu dengan total 57 orang. Dengan demikian dapat disimpulkan bahwa tingkat disiplin kerja karyawan guru Sekolah Pelita masih belum efektif disiplin kerja dalam mematuhi peraturan peratuan yang sudah ditetapkan oleh perusahaan. Kompensasi merupakan salah satu faktor yang dapat mempengaruhi peningkatan kinerja karyawan. Pada umumnya dengan kompensasi dapat mengambarkan kualitas dan skill mengajar seorang guru. Sistem kompensasi yang di berikan Sekolah Pelita Kasih, yaitu tidak ada bonus yang diberikan kepada guru yang berprestasi. Sehingga kurangnya dorongan atau motivasi terhadap guru di Sekolah Pelita Kasih.

Rumusan masalah Berdasarkan batasan masalah yang telah dikemukakan di atas, maka perumusan maslah dalam penelitian ini adalah sebagai berikut: (1) Apakah pengaruh kepemimpinan terhadap kinerja guru pada Sekolah Pelita Kasih? (2) Apakah pengaruh disiplin kerja terhadap kinerja guru pada Sekolah Pelita Kasih?, (3) Apakah pengaruh kompensasi terhadap kinerja guru pada Sekolah Pelita Kasih?, (4) Apakah pengaruh kepemimpinan, disiplin kerja dan kompensasi terhadap kinerja guru pada Sekolah Pelita Kasih?

Adapun tujuan dari penelitian ini adalah: (1) Untuk mengetahui pengaruh kepemimpinan terhadap kinerja guru pada Sekolah Pelita Kasih, (2) Untuk mengetahui pengaruh disiplin kerja terhadap kinerja guru pada Sekolah Pelita Kasih, (3) Untuk mengetahui pengaruh kompensasi terhadap kinerja guru pada Sekolah Pelita Kasih, (4) Untuk mengetahui pengaruh kepemimpinan, disiplin kerja dan Kompensasi terhadap kinerja guru pada Sekolah Pelita Kasih.

\section{METODE}

Penelitian ini dilaksanakan di Sekolah Pelita Kasih. Desain penelitian yang digunakan desain kausalitas. Penelitian ini menggunakan tenik pengambilan sampel non probability sampel yaitu dengan menggunakan teknik Sampling Jenuh adalah teknik penentuan sampel bila semua anggota populasi digunakan sebagai sampel. Hal ini sering dilakukan bila jumlah populasi relatif kecil, kurang dari 30 orang, atau penelitian yang ingin membuat generalisasi dengan kesalahan yang sangat kecil. Istilah lain sampel jenuh adalah sensus, dimana semua anggota populasi dijadikan sampel (Sugiyono, 2014: 85). Berdasarkan pengambilan sampel sensus yang digunakan diambil dari seluruh populasi 129. Penggunaan sampel digunakan dikarenakan dengan populasi relatif kecil sehingga penggunaan sampel diharapkan mampu memaksimalkan kinerja guru di Sekolah Pelita Kasih Batam.

Metode analisis data yang digunakan dalam penelitian ini adalah (1) Uji Kualitas Data yang meliputi: uji validitas dan uji reliabilitas; (2) Uji Pengaruh yang meliputi: (1) uji koefisien determinasi; (2) uji $\mathrm{T}$ (parsial);(3) Uji F (simultan).

\section{HASIL DAN PEMBAHASAN}

Hasil Penelitian Uji Validitas

Pengujian validitas instrumen menggunakan Analyst Correlate Bivariate untuk mencari correlation coefficient dari Pearson Product Moment dengan SPSS. Kemudian dibandingkan dengan nilai $r$ tabel untuk $\alpha=0.05$ dengan derajat kebebasan $\quad(\mathrm{dk}=\mathrm{n}-2) \quad$ sehingga 
didapatkan $r$ tabel. Untuk butir pernyataan dengan nilai koefisien korelasi ( $\mathrm{r}$ hitung) $>\mathrm{r}$ tabel maka butir pernyataan tersebut dinyatakan valid. Karena jumlah responden yang digunakan untuk uji validitas sebanyak
129 orang, maka nilai $r$ tabel dapat ditentukan dari $\mathrm{DK}=\mathrm{n}-2=129-2=127$ Nilar $r$ tabel dengan $\mathrm{dk}=127$ adalah 0.1729 Jadi, jika $r$ hitung $>r$ tabel maka item pertanyaan dinyatakan valid.

Tabel 2. Hasil Uji Validitas Kepemimpinan (X1)

\begin{tabular}{|c|c|c|c|c|}
\hline \multicolumn{5}{|c|}{ Item-Total Statistics } \\
\hline Item & $\begin{array}{l}\text { Corrected } \\
\text { elation }\end{array}$ & Item-Total & rtabel & Keterangan \\
\hline X1_1 & 0,653 & & \multirow{5}{*}{0,1729} & \multirow{5}{*}{ VALID } \\
\hline X1_2 & 0,810 & & & \\
\hline X1_3 & 0,816 & & & \\
\hline X1_4 & 0,759 & & & \\
\hline X1_5 & 0,780 & & & \\
\hline
\end{tabular}

Sumber: Hasil Pengolahan Data SPSS 21 (2019)

Dari hasil uji validitas pada variabel Kepemimpinan $\left(\mathrm{X}_{1}\right)$ terlihat bahwa semua item skor dari setiap pertanyaan adalah Corrected ItemTotal Correlation $>\mathrm{r}_{\text {tabel, }}$ hal ini menjelaskan bahwa $r_{\text {hitung }}>r_{\text {tabel }}$ yang berarti bahwa setiap instrumen dari item Pertanyaan dinyatakan valid. Dengan demikian maka kelima item pertanyaan dari variabel Kepemimpinan $\left(\mathrm{X}_{1}\right)$ dinyatakan valid dan dapat digunakan dalam pengujian selanjutnya.

Tabel 3. Hasil Uji Validitas Disiplin Kerja (X2)

\begin{tabular}{|c|c|c|c|}
\hline \multicolumn{4}{|c|}{ Item-Total Statistics } \\
\hline Item & Corrected Item-Total Correlation & $r_{\text {tabel }}$ & Keterangan \\
\hline $\mathrm{X} 2 \_1$ & 0,557 & \multirow{14}{*}{0,1729} & \multirow{14}{*}{ VALID } \\
\hline $\mathrm{X} 2 \_2$ & 0,564 & & \\
\hline $\mathrm{X} 2 \_3$ & 0,469 & & \\
\hline $\mathrm{X} 2 \_4$ & 0,595 & & \\
\hline $\mathrm{X} 2 \_5$ & 0,610 & & \\
\hline $\mathrm{X} 2 \_6$ & 0,571 & & \\
\hline $\mathrm{X} 2 \_7$ & 0,691 & & \\
\hline $\mathrm{X} 2 \_8$ & 0,584 & & \\
\hline X2_9 & 0,544 & & \\
\hline $\mathrm{X} 2 \_10$ & 0,572 & & \\
\hline $\mathrm{X} 2 \_11$ & 0,649 & & \\
\hline X2_12 & 0,625 & & \\
\hline X2_13 & 0,641 & & \\
\hline X2_14 & 0,574 & & \\
\hline
\end{tabular}

Sumber: Hasil Pengolahan Data SPSS 21 (2019)

Dari hasil uji validitas pada variabel Disiplin Kerja (X2) terlihat bahwa semua item skor dari setiap 
pertanyaan adalah Corrected ItemTotal Correlation > rtabel, hal ini menjelaskan bahwa rhitung> rtabel yang berarti. Setiap instrumen dari item pernyataan dinyatakan valid. Dengan demikian maka keempat belas

Tabel 4. Hasil Uji Validitas Kompensasi (X3)

\begin{tabular}{|c|c|c|c|}
\hline \multicolumn{4}{|c|}{ Item-Total Statistics } \\
\hline Item & Corrected Item-Total Correlation & $r_{\text {tabel }}$ & Keterangan \\
\hline X3_1 & 0,762 & \multirow{8}{*}{0,1729} & \multirow{8}{*}{ VALID } \\
\hline $\mathrm{X} 3 \_$ & 0,825 & & \\
\hline X3_3 & 0,815 & & \\
\hline X3_4 & 0,312 & & \\
\hline X3_5 & 0,745 & & \\
\hline X3_6 & 0,786 & & \\
\hline X3_7 & 0,769 & & \\
\hline X3_8 & 0,730 & & \\
\hline
\end{tabular}

Sumber: Hasil Pengolahan Data SPSS 21 (2019)

Dari hasil uji validitas pada yang berarti bahwa setiap instrumen variabel Kompensasi (X3) terlihat bahwa semua item skor dari setiap pertanyaan adalah Corrected ItemTotal Correlation > rtabel, hal ini menjelaskan bahwa rhitung> rtabel item pertanyaan dari variabel disiplin kerja (X2) dinyatakan valid dan dapat digunakan dalam pengujian selanjutnya. dari item pertanyaan dinyatakan valid.

Dengan demikian maka kedelapan item pertanyaan dari variabel kompensasi (X3) dinyatakan valid dan dapat digunakan dalam pengujian selanjutnya.

Tabel 5. Hasil Uji Validitas Kinerja Guru (Y)

\begin{tabular}{|c|c|c|c|}
\hline \multicolumn{4}{|c|}{ Item-Total Statistics } \\
\hline Item & Corrected Item-Total Correlation & $\mathrm{r}_{\text {tabel }}$ & Keterangan \\
\hline Y_1 & 0,464 & \multirow{18}{*}{0,1729} & \multirow{18}{*}{ VALID } \\
\hline Y_2 & 0,443 & & \\
\hline Y_3 & 0,424 & & \\
\hline Y_4 & 0,458 & & \\
\hline Y_5 & 0,667 & & \\
\hline Y_6 & 0,767 & & \\
\hline Y_7 & 0,631 & & \\
\hline Y_8 & 0,583 & & \\
\hline Y_9 & 0,479 & & \\
\hline Y_10 & 0,582 & & \\
\hline Y_11 & 0,591 & & \\
\hline Y_12 & 0,621 & & \\
\hline Y_13 & 0,603 & & \\
\hline Y_14 & 0,579 & & \\
\hline Y_15 & 0,652 & & \\
\hline Y_16 & 0,607 & & \\
\hline Y_17 & 0,612 & & \\
\hline Y_18 & 0,575 & & \\
\hline
\end{tabular}




\begin{tabular}{|r|c|c|l|}
\hline \multicolumn{3}{|c|}{ Item-Total Statistics } \\
\hline Item & Corrected Item-Total Correlation & r $_{\text {tabel }}$ & Keterangan \\
\hline Y_19 & 0,644 & & \\
\hline Y_20 & 0,475 & & \\
\hline Y_21 & 0,580 & & \\
\hline
\end{tabular}

Sumber: Hasil Pengolahan Data SPSS 21 (2019)

Dari hasil uji validitas pada variabel kinerja guru (Y) terlihat bahwa semua item skor dari setiap pertanyaan adalah Corrected ItemTotal Correlation > rtabel, hal ini menjelaskan bahwa rhitung> rtabel yang berarti Setiap instrumen dari item Hasil Uji Reliabilitas

Suatu instrument dapat memiliki tingkat kepercayaan yang tinggi (konsisten) jika hasil dari pengujian instrume nttersebut menunjukkan hasil yang tetap. Dengan demikian, masalah reliabilitas pertanyaan dinyatakan valid. Dengan demikian maka kedua puluh satu item pertanyaan dari variabel Kinerja Guru (Y) dinyatakan valid dan dapat digunakan dalam pengujian selanjutnya.

instrumen berhubungan dengan masalah ketepatan hasil. Berikutnya dilakukan pengujian reliabilitas instrument. Hasil perhitungan reliabilitas instrument dengan menggunakan Cronbach alpha ditunjukan tabel ini dibawah ini:

Tabel 6 Indeks Koefisien Reliabilitas

\begin{tabular}{|l|l|l|}
\hline No. & Nilai Interval & Kriteria \\
\hline 1. & $<0,20$ & Sangat rendah \\
\hline 2. & $0,20-0,399$ & Rendah \\
\hline 3. & $0,40-0,599$ & Cukup \\
\hline 4. & $0,60-0,799$ & Tinggi \\
\hline 5. & $0,80-1,00$ & Sangat tinggi \\
\hline
\end{tabular}

Sumber: (Wibowo, 2012: 53)

Tabel 7. Hasil Uji Reliabilitas

\begin{tabular}{|c|c|c|c|r|l|l|}
\hline No & Variabel & $\begin{array}{c}\text { Jumlah } \\
\text { Sampel }\end{array}$ & $\begin{array}{c}\text { Nilai Crobanch's } \\
\text { Alpha }\end{array}$ & Standar & Keterangan & $\begin{array}{c}\text { Kriteria } \\
\text { Hubungan }\end{array}$ \\
\hline 1 & $\mathrm{X} 1$ & 129 & 0,822 & 0,60 & Reliabel & Sangat Tinggi \\
\hline 2 & $\mathrm{X} 2$ & 129 & 0,852 & 0,60 & Reliabel & Sangat Tinggi \\
\hline 3 & $\mathrm{X} 3$ & 129 & 0,873 & 0,60 & Reliabel & Sangat Tinggi \\
\hline 4 & $\mathrm{Y}$ & 129 & 0,897 & 0,60 & Reliabel & Sangat Tinggi \\
\hline
\end{tabular}

Sumber: Hasil Pengolahan Data SPSS 21 (2019)

\section{Uji Pengaruh}

Koefisien Determinasi (R2)

Nilai koefisien determinasi adalah antara nol dan satu. Bila $\mathrm{R}=0$ berarti diantara variabel bebas (independen variabel) dengan variabel terikat (dependen variabel) tidak ada hubungannya, sedangkan bila $\mathrm{R}=1$ berarti diantara variabel bebas (independen variabel) dengan variabel terikat (dependen variabel) mempunyai hubungan kuat. Maka hasil penelitian yang diperoleh sesuai pada Tabel 8 adalah: 
Tabel 8. Hasil Uji R Square

Model Summary ${ }^{\mathrm{b}}$

\begin{tabular}{|l|l|l|l|l|}
\hline Model & $R$ & R Square & Adjusted R Square & Std. Error of the Estimate \\
\hline 1 & $.624^{\mathrm{a}}$ & .389 & .375 & 5.757 \\
\hline
\end{tabular}

Predictors: (Constant), Kompensasi, Kepemimpinan, Disiplin Kerja

Dependent Variable: Kinerja Guru

Sumber: Hasil Pengolahan Data SPSS 21 (2019)

Berdasarkan Tabel 4.23 Hasil diatas didapatkan hasil uji R Square bernilai 0,389 . Hal ini berarti bahwa antara kepemimpinan, disiplin kerja dan kompensasi, mempunyai hubungan terhadap kinerja guru sebesar $38,9 \%$ sedangkan sisanya $(100$ $\%-38,9 \%$ J $=61,1 \%$ dipengaruhi oleh faktor lain di luar model yang tidak dijelaskan dalam penelitian ini.

\section{Uji Hipotesis Hasil Uji T}

Tabel 9. Hasil Uji t

Coefficients $^{\mathrm{a}}$

\begin{tabular}{|c|c|c|c|c|c|c|c|}
\hline \multirow[t]{2}{*}{ Model } & \multicolumn{2}{|c|}{$\begin{array}{l}\text { Unstandardized } \\
\text { Coefficients }\end{array}$} & \multirow{2}{*}{$\begin{array}{l}\text { Standardized } \\
\text { Coefficients } \\
\text { Beta }\end{array}$} & \multirow[t]{2}{*}{$T$} & \multirow[t]{2}{*}{ ig. } & \multicolumn{2}{|c|}{$\begin{array}{l}\text { Collinearity } \\
\text { Statistics }\end{array}$} \\
\hline & $B$ & Std. Error & & & & $\begin{array}{l}\text { Toleranc } \\
\text { e }\end{array}$ & VIF \\
\hline (Constant) & 41.060 & 6.569 & & 6.251 & 000 & & \\
\hline Kepemimpinan & 1.012 & 260 & 315 & 3.891 & 000 & .746 & 1.341 \\
\hline Disiplin Kerja & 606 & 116 & 431 & 5.211 & 000 & .715 & 1.399 \\
\hline Kompensasi & -.330 & 105 & -.230 & -3.156 & 002 & .916 & 1.091 \\
\hline
\end{tabular}

a. Dependent Variable: Kinerja Guru

Sumber: Hasil Pengolahan Data SPSS 21 (2019)

Berdasarkan tabel diatas dapat disimpulkan sebagai berikut:

(1) Untuk variabel Kepemimpinan thitung $=3,891$ dan nilai signifikansi 0,000 sedangkan $t_{\text {tabel }}=1,979$. Secara statistik dapat diambil kesimpulan bahwa jika $\mathrm{t}_{\text {hitung }}>$

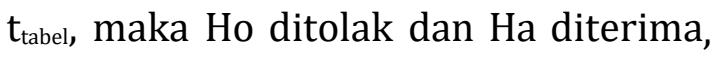
artinya terdapat pengaruh yang
Pengujian ini bertujuan untuk menguji tentang masing-masing variabel bebas (independent) apakah berpengaruh secara signifikan terhadap variabel terikat (dependent) secara parsial dengan $\alpha=0.05$ dan juga tentang penerimaan atau penolakan hipotesa. Maka hasil penelitian yang diperoleh sesuai pada Tabel 4.24 adalah: signifikan Kepemimpinan terhadap Kinerja Guru. (2) Untuk variabel disiplin kerja hitung $=5,211$ dan nilai signifikansi 0,000 sedangkan $\mathrm{t}_{\text {tabel }}=1,979$. Secara statistik dapat diambil kesimpulan bahwa jika $t_{\text {hitung }}>$ $t_{\text {tabel, }}$ maka Ho ditolak dan Ha diterima, artinya terdapat pengaruh yang signifikan Disiplin Kerja terhadap 
Kinerja Guru. (3) Untuk variabel penghargaan hitung $=-1,3156$ dan nilai signifikansi 0,002 sedangkan tabel=1,979. Secara statistik dapat diambil kesimpulan bahwa jika $t_{\text {hitung }}<$

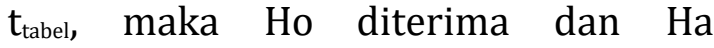
diditolak, artinya terdapat pengaruh

Tabel 10 Hasil Uji F

ANOVA $^{\mathrm{a}}$

\begin{tabular}{|r|r|l|l|l|l|}
\hline Model & Sum of Squares & Df & Mean Square & $\mathrm{F}$ & Sig. \\
\hline Regression & 2639.762 & 3 & 879.921 & 26.547 & $.000^{\mathrm{b}}$ \\
Residual & 4143.230 & 125 & 33.146 & & \\
Total & 6782.992 & 128 & & & \\
\hline
\end{tabular}

Dependent Variable: Kinerja Guru

Predictors: (Constant), Kompensasi, Kepemimpinan, Disiplin Kerja

Sumber: Hasil Pengolahan Data SPSS 21 (2019)

\section{Pembahasan}

Berdasarkan nilai hasil pengolahan data telah dilakukan menggunakan metode-metode yang dijelaskan pada sub bab sebelumnya, maka dapat dilakukan uji hipotesis yang bertujuan untuk menguji hipotesis yang bertujuan untuk menguji hipotesis yang telah dijelaskan pada pembahasan metodelogi penelitian. Hasil uji hipotesis adalah sebagai berikut:

\section{Pengaruh Kepemimpinan Terhadap} Kinerja Guru Sekolah Pelita Kasih.

Berdasarkan hasil penelitian yang telah diuraikan dengan menggunakan SPSS versi 21, diketahui bahwa Kepemimpinan $\left(\mathrm{X}_{1}\right)$ mempengaruh signifikan terhadap kinerja guru. Kesimpulan tersebut didasarkan pada hasil uji statistik $t$ yang menunjukkan hasil t hitung $\left(\mathrm{X}_{1}\right)$ sebesar 3,891 lebih besar pada nilai t tabel sebesar 1,979. Selain itu, untuk melihat ada tidaknya pengaruh bisa dengan membandingkan nilai signifikan variabelnya. Apabila nilai signifikan yang ditunjukkan dibawah 0,05 maka dapat disimpulkan signifikan negatif kompensasi terhadap Kinerja guru.

\section{Hasil Uji F}

Pengujian ini bertujuan untuk menguji apakah semua variable bebas (independent) yang dimasukan dalam model mempunyai pengaruh secara bersama-sama terhadap variabel terikat (dependent). bahwa terdapat hubungan antara variabel independen dengan variabel dependen yang diteliti. Nilai signifikan hasil uji t stastitik kepemimpinan $\left(\mathrm{X}_{1}\right)$ sebesar 0,000 di bawah alpha yang telah ditentukan yaitu 0,05 maka dapat disimpulkan kepemimpinan $\left(\mathrm{X}_{1}\right)$ berpengaruh signifikan dan positif terhadap kinerja guru(Y).

Dengan demikian, hipotesis pertama diterima hal ini menunjukan hasil penelitian ini sejalan dengan penelitian yang dilakukan oleh (Endang Putra \& Yunita, 2014). Hasil penelitian menunjukkan bahwa kepemimpinan berpengaruh positif dan signifikan terhadap kinerja guru.

Pengaruh Disiplin Kerja Terhadap Kinerja Guru Sekolah Pelita Kasih.

Berdasarkan hasil penelitian yang telah diuraikan dengan menggunakan SPSS versi 21, diketahui bahwa disiplin kerja $\left(\mathrm{X}_{2}\right)$ mempengaruh signifikan kinerja guru pada Sekolah Pelita Kasih. Kesimpulan tersebut didasarkan pada hasil uji statistik t yang menunjukkan hasil t hitung disiplin kerja $\left(\mathrm{X}_{2}\right)$ sebesar 5,211 lebih besar pada nilai $t$ table 
sebesar 1,979. Selain itu, untuk melihat ada tidaknya pengaruh bisa dengan membandingkan nilai signifikan variabelnya. Apabila nilai signifikan yang ditunjukkan dibawah 0,05 maka dapat disimpulkan bahwa terdapat hubungan antara variabel independen dengan variabel dependen yang diteliti. Nilai signifikan hasil uji $t$ stastitik disiplin kerja $\left(\mathrm{X}_{2}\right)$ sebesar 0,000 dibawah alpha yang telah ditentukan yaitu 0,05 maka dapat disimpulkan disiplin kerja $\left(\mathrm{X}_{2}\right)$ berpengaruh positif dan signifikan terhadap kinerja guru pada Sekolah Pelita Kasih (Y). Dengan demikian, hipotesis kedua diterima hal ini menunjukan hasil penelitian ini sejalan dengan penelitian yang dilakukan oleh (Suparno \& Sudarwati, 2014), Hasil penelitian menunjukkan bahwa disiplin kerja berpengaruh positif dan signifikan terhadap kinerja karyawan.

\section{Pengaruh Kompensasi Terhadap Kinerja Karyawan pada Sekolah Pelita Kasih}

Berdasarkan hasil penelitian yang telah diuraikan dengan menggunakan SPSS versi 21, diketahui bahwa kompensasi $\left(\mathrm{X}_{3}\right)$ mempengaruh signifikan kinerja guru pada Sekolah Pelita Kasih Kesimpulan tersebut didasarkan pada hasil uji statistik $\mathrm{t}$ yang menunjukkan hasil $t$ hitung kompensasi $\left(X_{3}\right)$ sebesar -3,156 lebih kecil pada nilai t table sebesar 1,979. Selain itu, untuk melihat ada tidaknya pengaruh bisa dengan membandingkan nilai signifikan variabelnya. Apabila nilai signifikan yang ditunjukkan dibawah 0,05 maka dapat disimpulkan bahwa terdapat hubungan antara variabel independen dengan variabel dependen yang diteliti. Nilai signifikan hasil uji $\mathrm{t}$ stastitik kompensasi $\left(\mathrm{X}_{3}\right)$ sebesar 0,002 dibawah alpha yang SIMPULAN DAN SARAN telah ditentukan yaitu 0,05 maka dapat disimpulkan kompensasi $\left(\mathrm{X}_{3}\right)$ berpengaruh signifikan negatif terhadap kinerja guru (Y).

Dengan demikian, hipotesis ketiga ditolak hal ini menunjukan hasil penelitian ini sejalan dengan penelitian yang dilakukan oleh (SahlanIkhsan, A.Mekel, \& Trang, 2015), Hasil penelitian menunjukkan bahwa kompensasi berpengaruh negatif dan signifikan terhadap kinerja karyawan.

Pengaruh Kepemimpinan, Disiplin Kerja, Kompensasi Terhadap Kinerja Guru pada Sekolah Pelita Kasih.

Berdasarkan hasil penelitian yang telah diuraikan dengan menggunakan SPSS versi 21, diketahui bahwa kepemimpinan $\left(\mathrm{X}_{1}\right)$, disiplin kerja $\left(\mathrm{X}_{2}\right)$ dan kompensasi $\left(\mathrm{X}_{3}\right)$, mempengaruh signifikan kinerja guru pada Sekolah Pelita Kasih. Kesimpulan tersebut didasarkan pada hasil uji $f$ yang menunjukkan hasil $f$ untuk variabel kepemimpinan $\left(\mathrm{X}_{1}\right)$, disiplin kerja $\left(\mathrm{X}_{2}\right)$ dan kompensasi $\left(\mathrm{X}_{3}\right)$, sebesar lebih besar 26,547 pada nilai $\mathrm{f}$ tabel sebesar 2,675. Selain itu, untuk melihat ada tidaknya pengaruh bisa dengan membandingkan nilai signifikan variabelnya. Apabila nilai signifikan yang ditunjukkan dibawah 0,05 maka dapat disimpulkan maka dapat disimpulkan terdapat hubungan antara variabel independen dengan variabel dependen yang diteliti. Nilai signifikan hasil uji $\mathrm{f}$ untuk variabel kepemimpinan $\left(\mathrm{X}_{1}\right)$, disiplin kerja $\left(\mathrm{X}_{2}\right)$ dan kompensasi $\left(\mathrm{X}_{3}\right)$ sebesar 0.000 dibawah alpha yang telah ditentukan yaitu 0,05 maka dapat disimpulkan variabel kepemimpinan $\left(\mathrm{X}_{1}\right)$, disiplin kerja $\left(\mathrm{X}_{2}\right)$ dan kompensasi (X3) secara simultan berpengaruh terhadap kinerja guru (Y). 
Berdasarkan uraian dan analisa pembahasan yang telah dikemukakan pada bab sebelumnya, maka dapat ditarik kesimpulan sebagai berikut:

(1) Hasil pengujian pada hipotesis H1 diperoleh bahwa kepemimpinan berpengaruh signifikan positif terhadap kinerja guru. Hasil pengujian ini konsisten dengan hasil penelitian (Endang Putra \& Yunita, 2014). (2) Hasil pengujian pada hipotesis $\mathrm{H} 2$ diperoleh bahwa disiplin kerja berpengaruh signifikan positif terhadap kinerja guru. Hasil pengujian ini konsisten dengan hasil penelitian (Suparno \& Sudarwati, 2014). (3) Hasil pengujian pada hipotesis H3 diperoleh bahwa kompensasi berpengaruh signifikan negatif terhadap kinerja guru. Hasil pengujian ini konsisten dengan hasil penelitian (SahlanIkhsan et al., 2015). (4) Hasil pengujian pada hipotesis H1, H2, H3 diperoleh bahwa kepemimpinan, disiplin kerja dan kompensasi secara simultan berpengaruh signifikan terhadap kinerja guru pada Sekolah Pelita Kasih. Disimpulkan bahwa ketiga variabel tersebut telah menjadi daya dorong yang kuat bagi guru Sekolah Pelita Kasih. Ketiga Variabel tersebut di atas telah menjadi bukti bahwa selama ini kepemimpinan, disiplin kerja dan kompensasi yang diberikan oleh pihak atasan telah dapat member pengaruh kuat bagi setiap kinerja guru.

\section{DAFTAR PUSTAKA}

Aparicio Guterres, L., \& Gede Supartha, W. (2016). Pengaruh Gaya Kepemimpinan dan Motivasi Kerja Terhadap Kinerja Guru, 3, 429-454.

Arifin, S. (2012). Leadership Ilmu dan Seni Kepemimpinan (Asli). Jakarta: Mitra Wacana Media.

Bungawati, \& Syafaruddin. (2016). Pengaruh Kepemimpinan,
Motivasi Kerja dan Disiplin Kerja terhadap Kinerja Guru SMKN 7 Makassar. Journal Competitiveness, 10(2), 1-15.

Darmawan, D. (2013). PrinsipPrinsip Perilaku Organisasi. (A. Al Adhim, Ed.). Surabaya: Pena Semesta (PT. JePe Press Media Utama).

H.M.Yani. (2012). Manajemen Sumber Daya Manusia. Mitra Wacana Media.

Hafied, H. (2017). Leadership, Compensation, Work Discipline Are Able To Improve Performance Clerk PD Market City Of Makassar, 6(3).

Hasibuan, M. (2012). Manajemen Sumber Daya Manusia. Jakarta: Bumi Aksara.

Hasibuan, M. (2017). Manajemen Sumber Daya Manusia (Revisi). Jakarta: Bumi Aksara.

Lukiyana, \& Sonata Tualaka, D. (2016). Pengaruh Kompensasi dan Fasilitias Kerja Terhadap Kinerja Guru Dengan Disiplin Kerja Sebagai Variabel Intervening pada TK Misi bagi Bangsa SeJakarta. Online Internasional \& Nasional, 3(2), 33-45.

Mamesah, A. M. C., Kawet, L., \& Lengkong, V. P. K. (2016). Pengaruh Lingkungan Kerja, Disiplin Kerja Dan Loyalitas Kerja Terhadap Kinerja Karyawan Pada LPP RRI MANADO. EMBA, 4(3), 600-611.

Mondy, W. (2008). Manajemen Sumber Daya Manusia. (N. Indra Sallama, Y. Sri Hayati, \& A. Maulana, Eds.) (2nd ed.). Jakarta: Erlangga.

Muhidin, S. A., \& Abdurahman, M. (2007). Analisis Korelasi, Regresi dan Jalur dalam Penelitian. Bandung: PUSTAKA SETIA.

Oktiyani, R., \& Nainggolan, K. (2016). Analisis Pengaruh Kompensasi dan Lingkungan Kerja Terhadap Kinerja Guru di SMA Negeri 1 Klaten. Ecodemica, IV(2), 136-145. 
Priyatno, D. (2012). Cara Kilat Belajar Analisis Data Dengan SPSS 20. Yogyakarta: Andi Yogyakarta.

Riduwan. (2008). Belajar Mudah Penelitian Untuk Guru, Karyawan dan Peneliti Pemula. (akdon, Ed.). bandung: Alfabeta.

Rivai, V., \& Jauvani Sagala, E. (2011). Manajemen Sumber Daya Manusia untuk Perusahaan. Bandung: Raja Grafindo Persada.

SahlanIkhsan, N., A.Mekel, P., \& Trang, I. (2015). Pengaruh Lingkungan Kerja, Kepuasan Kerja dan Kompensasi Terhadap Kinerja Karyawan Pada PT.BANK SULUT CABANG AIRMADIDI. EMBA, 3(1), 52-62.

Sanusi, A. (2012). Metodologi Penelitian Bisnis: Disertai Contoh Proposal Penelitian Bidang Ilmu Ekonomi dan Manajemen. Malang: Salemba Empat.

Sedarmayanti.(2011). Manajemen Sumber Daya Manusia Reformasi Birokrasi dan Manajemen Pegawai Negeri Sipil. Yogyakarta: Refika Aditama.

Sri Nugraheni, A., \& Rahmayanti, R. (2016). Pengaruh Disiplin Kerja Terhadap Kinerja Guru di MI Al Islam Tempel dan MI Al Ihsan Medari. Fakultas IImu Tarbiyah Dan Keguruan, 1(November), 277-294.

Sugiyono. (2012). Metode Penelitian Bisnis. Bandung: CV Alfabeta. Sugiyono. (2014). Metode Penelitian Kuantitatif, Kualitatif dan $R \& D$. Bandung: Alfabeta.

Sugiyono. (2016). Metode Penelitian Manajemen. (Setiyawami, Ed.). Bandung: Alfabeta.

Sunyoto, D. (2012a). Manajemen Sumber Daya Manusia.

Jakarta: PT. Buku Seru.
Sunyoto, D. (2012b). Teori, Kuesioner dan Analisis Data Sumber Daya Manusia. Jakarta: PT. Buku Seru.

Suparno, \& Sudarwati. (2014). Pengaruh Motivasi, Disiplin Kerja Dan Kompetensi Terhadap Kinerja Pegawai Dinas Pendidikan Kabupaten Sragen. Jurnal Paradigma, 12(1), 12-25.

Supeno, Suseno, I., \& Miranti, I. (2017). Pengaruh Motivasi, Disiplin Kerja dan Gaya Kepemimpinan Kepala Sekolah Terhadap Kinerja Guru Bahasa Inggris Smp Dki Jakarta, 9(1), 90-99.

Supriyatno, A., Subiyanto, \& Tawil. (2016). Pengaruh Sertifikasi Pendidik, Kompentensi Guru dan Kepemimpinan Kepada Sekolah Terhadap Kinerja Guru SMA. Profesi Pendidik, 3(November), 171- 181.

Sutrisno, E. (2011). Manajemen Sumber Daya Manusia.Jakarta: Kencana Prenada Media.

Syamra, Y. (2016). Pengaruh Kompensasi Finansial dan Motivasi Kerja Guru Terhadap Kinerja Guru SMK Negeri Pariwisata Di Kota Padang. Economic and Economic Education, $4(2)$.

Thaief, I., Baharuddin, A., Priyono, \& Idrus, M. S. (2015). Effect of training, compensation and work discipline against employee job performance: (Studies in the office of PT. PLN (Persero) Service Area and Network Malang). Review of European Studies, 7(11), 23-33.

https://doi.org/10.5539/res.v7n11p23

Wibowo, A. E. (2012). Aplikasi Praktis SPSS Dalam Penelitian. Yogyakarta: Gava Media.

Yuniarsih, T., \& Suwatno. (2011). Manajemen Sumber Daya Manusia Teori, Aplikasi dan Isu Penelitian. Bandung: Alfabeta. 